\title{
ANALISIS KEMAMPUAN CURRENT RATIO, RETURN ON TOTAL ASSETS, DEBT TO TOTAL ASSETS, TOTAL ASSETS TURNOVER, DAN PRICE EARNING RATIO DALAM MEMPREDIKSI PERTUMBUHAN LABA PADA PERUSAHAAN MANUFAKTUR DI BEI TAHUN 2013-2017
}

\author{
Frenita Damayanti, Lardin Korawijayanti ${ }^{\star}$, dan Tutik Dwi Karyanti \\ Program Studi Akuntansi Manajerial, Jurusan Akuntansi \\ Politeknik Negeri Semarang, Jl, Prof. Soedarto,SH, Tembalang, Semarang \\ lardinkorawijayanti@yahoo.co.id; tutikdwikaryanti@yahoo.co.id
}

\begin{abstract}
This study aims to examine the effect of current ratio, return on total assets, debt to total assets, total asset turnover, and price earning ratio in predicting profit growth both simultaneously and partially. The sample in this study were 55 manufacturing companies listed on the Indonesia Stock Exchange during 20132017. The collected data will be processed and then analyzed using multiple linear regression. The test is carried out using the help of the SPSS for Windows program.

The results of the analysis show that the current ratio, return on total assets, debt to total assets, total asset turnover, and price earning ratio simultaneously influence in predicting earnings growth. Partially, only return on total assets and total assets turnover has a significant effect on predicting earnings growth. The value of adjusted $R$ square is 7,7\%. This means that 7,7\% of profit growth can be explained by independent variable (current ratio, return on total assets, debt to total assets, total asset turnover, and price earning ratio). While the remaining $(92,3 \%)$ is explained by other variables or other causes.

Keywords: Profit Growth, Current Ratio, Return On Total Assets, Debt To Total Assets, Total Assets Turnover, Price Earning Ratio.
\end{abstract}

\footnotetext{
ABSTRAK:Penelitian ini bertujuan untuk menguji pengaruh current ratio, return on total assets, debt to total assets, total assets turnover, dan price earning ratio dalam memprediksi pertumbuhan laba baik secara simultan maupun parsial. Sampel pada penelitian ini adalah 55 perusahaan manufaktur yang terdaftar di Bursa Efek Indonesia selama tahun 2013-2017.Data yang terkumpul akan diolah dan selanjutnya dianalisis dengan menggunakan Regresi Linier Berganda. Pengujian tersebut dilakukan dengan menggunakan bantuan program SPSS for Windows.

Hasil analisis menunjukkan, bahwa variabel current ratio, return on total assets, debt to total assets, total assets turnover, dan price earning ratiosecara simultan berpengaruh dalam memprediksi pertumbuhan laba. Secara parsial, hanya return on total assetsdan total assets turnover yang berpengaruh secara signifikan dalam memprediksi pertumbuhan laba. Nilai adjusted $R$ square adalah 7,7\%. Ini berarti bahwa $7,7 \%$ dari pertumbuhan laba dapat dijelaskan oleh variabel independen (current ratio, return on total assets, debt to total assets, total assets turnover, dan price earning ratio). Sedangkan sisanya (92,3\%) dijelaskan oleh variabel lain atau sebab lain.

Kata Kunci: Pertumbuhan Laba, Current Ratio, Return On Total Assets, Debt To Total Assets, Total Assets Turnover, Price Earning Ratio.
} 


\section{PENDAHULUAN}

Setiap perusahaan perlu dinilai hasil kinerjanya. Salah satu hal yang dapat dinilai adalah dari unsur keuangannya. Keuangan merupakan salah satu faktor terpenting perusahaan untuk dapat melihat perkembangan kinerjanya. Hal tersebut dapat direfleksikan dalam suatu laporan yang menggambarkan perkembangan finansial perusahaan dari suatu periode tertentu.Laporan ini akan menunjukkan perubahan posisi keuangan dan kinerja dari sebuah organisasi atau badan usaha. Dengan kata lain, laporan ini menggambarkan indikator kesuksesan suatu perusahaan dalam mencapai tujuannya. Laporan tersebut biasa disebut dengan laporan keuangan.

Menurut Hery (2018:3), laporan keuangan berfungsi sebagai alat informasi yang menghubungkan perusahaan dengan pihak-pihak yang berkepentingan, yang menunjukkan kesehatan keuangan perusahan dan kinerja perusahaan. Laporan keuangan dapat dikatakan sebagai alat perusahaan yang dapat memberikan informasi atau kondisi keuangan dan hasil yang dicapai perusahaan untuk periode tertentu. Untuk melihat kesehatan financial perusahaan dapat dilihat dari laporan keuangannya.

Menurut Kasmir (2010:28), secara umum ada lima jenis laporan keuangan yang biasa disusun, yaitu: neraca, laporan laba rugi, laporan perubahan modal, laporan arus kas, dan laporan catatan atas laporan keuangan.Fokus utama laporan keuangan adalah informasi laba perusahaan pada suatu periode tertentu. Akan tetapi, laba saja tidak cukup untuk mengetahui kinerja perusahaan karena laba hanyalah kondisi umum perusahaan yang menggambarkan kondisi di masa lalu. Mereka membutuhkan prediksi kondisi perusahaan di masa mendatang yang lebih spesifik untuk menentukan keputusan mereka. Laporan keuangan memuat informasi keuangan yang dapat menjelaskan kinerja perusahaan. Dengan menggunakan laporan keuangan, para pelaku bisnis ini dapat memperoleh informasi yang mereka butuhkan. Akan tetapi, laporan keuangan tersebut masih perlu untuk diproses kembali agar dapat memberikan informasi lainnya.

Salah satu prediksi kondisi perusahaan di masa mendatang yang dibutuhkan oleh pelaku bisnis adalah pertumbuhan labanya. Dengan melihat pertumbuhan laba perusahaan maka dapat dilihat juga kesehatan keuangannya serta prospek perusahaan ke depannya. Pertumbuhan laba merupakan hasil dari penilaian kinerja perusahaan. Kinerja perusahaan dapat dinilai dengan menganalisis rasio keuangan.

Ada beberapa metode dalam menganalisis dan menilai kondisi keuangan pada perusahaan serta pertumbuhan labanya. Salah satu cara dari beberapa metode tersebut adalah dengan mengganalisis rasio keuangan.

Analisis rasio keuangan yang didasarkan pada data dan kondisi masa lalu dapat digunakan untukmenilai resiko dan peluang di masa yang akan datang. Menurut Hanafi dan Halim (2009:76), pada umumnya rasio terdiri dari rasio likuiditas, rentabilitas/profitabilitas, solvabilitas, aktifitas, dan pasar.

"Rasio likuiditas merupakan rasio yang menggambarkan kemampuan perusahaan dalam memenuhi kewajiban (utang) jangka pendek (Fred Weston dalam Kasmir, 2010:129). Current ratio mengukur kemampuan perusahaan memenuhi hutang jangka pendeknya dengan menggunakan aktiva lancarnya (aktiva yang akan berubah menjadi kas dalam waktu satu tahun atau satu siklus akuntansi ( Hanafi dan Halim, 2009:77). Pada rasio ini dapat diketahui sejauh mana aktiva lancar dapat digunakan untuk menutupi hutang jangka pendeknya. Semakin besar perbandingan aktiva lancar dengan utang lancar maka artinya semakin tinggi pula kemampuan 
perusahaan dalam menutupi kewajiban utang lancarnya. Akan tetapi, apabila current ratio terlalu tinggi bukan berarti perusahaan tersebut dalam keadaan keuangan yang baik. Bisa jadi perusahaan tersebut tidak mengalokasikan aktiva lancarnya secara efisien.

"Rasio profitabilitas mengukur kemampuan perusahaan menghasilkan keuntungan (profitabilitas) pada tingkat penjualan, aset, dan modal saham yang tertentu. Ada tiga rasio yang sering dibicarakan, yaitu: profit margin, Return on Total Assets (ROA), dan Return on Equity (ROE). Return on Total Assets mengukur kemampuan perusahaan menghasilkan laba bersih berdasarkan tingkat aset tertentu" ( Hanafi dan Halim, 2009:83). Dengan ROA dapat diukur tingkat efisiensi penggunaan modal secara menyeluruh. ROA berfungsi untuk membantu menilai seberapa baik suatu perusahaan dapat mengkonversi investasi asetnya menjadi laba (profit). Rasio yang lebih tinggi menunjukan bahwa perusahaan tersebut lebih efisien dalam mengelola asetnya untuk menghasilkan jumlah laba bersih yang lebih besar. Sehingga kriteria kinerja manajemen yang baik adalah perusahaan dengan ROA yang tinggi. Karena ini berarti tingkat pengembalian investasinya juga tinggi.

"Rasio solvabilitas mengukur kemampuan perusahaan memenuhi kewajiban-kewajiban jangka panjangnya. Perusahaan yang tidak solvable adalah perusahaan yang total hutangnya lebih besar dibandingkan total asetnya. Rasio ini mengukur likuiditas jangka panjang perusahaan dan dengan demkian memfokuskan sisi kanan neraca" (Hanafi dan Halim, 2009:81). Rasio ini mengukur tingkat kesehatan financial perusahaan berdasarkan utang yang dimiliki perusahaan. Utang yang terlalu tinggi berdampak terhadap risiko yang akan dihadapi perusahaan di masa yang akan datang yaitu kebangkrutan.
Debt to total assets menekankansejauh mana utang perusahaan dapat ditutupi oleh total aset perusahaan. Semakin kecil debt ratio maka semakin baik tingkat kesehatan financial perusahan.

Kasmir (2010:172) menyebutkan, "Rasio aktivitas merupakan rasio yang digunakan untuk mengukur efektivitas perusahaan dalam menggunakan aktiva yang dimilikinya. Atau dapat pula dikatakan rasio ini digunakan untuk mengukur tingkat efisiensi (efektivitas) pemanfaatan sumber daya perusahaan".Total assets turnover merupakan rasio yang membandingkan penjualan bersih dengan total asset. TAT mempunyai fungsi untuk mengukur kemampuan perusahaan menggunakan total asetnya dalam menghasilkan penjualan bersih. Semakinbesar TAT menunjukkan semakin efisien penggunaan seluruh aktiva perusahaan untuk menunjang kegiatan penjualan. Hal ini menunjukkan bahwa kinerjaperusahaan semakin baik.

Menurut Hanafi dan Halim (2009:84), Rasio pasar mengukur harga pasar relatif terhadap nilai buku. Sudut pandang rasio ini lebih banyak pada sudut investor (atau calon investor), meskipun pihak manajemen juga berkepentingan terhadap rasio ini. Price Earning Ratio (PER) melihat harga saham relatif terhadap earningnya. Perusahaan dengan PER yang tinggi merupakan perusahaan dengan prospek yang baik atau perusahaan yang dapat diharapkan akan mempunyai pertumbuhan yang tinggi. Akan tetapi, dari segi investor, PER yang terlalu tinggi dianggap tidak menarik karena kemungkinan harga saham untuk naik lagi sangat kecil.

Perusahaan manufaktur adalah suatu perusahaan yang aktivitasnya mengelola bahan mentah atau bahan baku menjadi barang jadi lalu menjualnya kepada konsumen. kegiatan ini disebut dengan proses produksi. Perusahaan manufaktur 
terdiri dari sektor industri dasar dan kimia, aneka industri, dan industri barang konsumsi. Tentunya masyarakat tidak bisa lepas dari perusahaan manufaktur untuk kehidupan sehari-hari. Karena semua produknya dibutuhkan baik untuk konsumsi rumah tangga maupun untuk bisnis. Sehingga sangat mungkin apabila perusahaan manufaktur akan terus meningkat karena terus digunakan. Dengan alasan tersebut, diharapkan perusahaan manufaktur dapat meningkat pertumbuhannya. Akan tetapi masih diperlukan prediksi pertumbuhan laba agar pihak-pihak yang berkepentingan dapat menentukan keputusannya khususnya di bidang keuangan.

Penelitian ini bertujuan untuk menganalisis kemampuan current ratio, return on total assets, debt to total assets, total assets turnover, dan price earning ratio dalam memprediksi pertumbuhan laba pada perusahaan manufaktur di BEI tahun 2013-2017

\section{LANDASAN TEORI}

\section{Signalling Theory}

Menurut Brigham \& Houston (2014:186), sinyal (signal) merupakan suatu tindakan yang diambil oleh manajemen suatu perusahaan memberikan petunjuk kepada investor tentang bagaimana manajemen menilai prospek perusahaan tersebut.

Sari dan Zuhrotun (2006:5) berpendapat bahwa signaling theory mengemukakan tentang bagaimana seharusnya sebuah perusahaan memberikan sinyal kepada pengguna laporan keuangan. Sinyal ini berupa informasi mengenai apa yang sudah dilakukan oleh manajemen untuk merealisasikan keinginan pemilik. Sinyal dapat berupa promosi atau informasi lain yang menyatakan bahwa perusahaan tersebut lebih baik daripada perusahaan lain.

Laba merupakan sinyal yang disampaikan oleh manajer ke pasar. Jika manajer mempunyai keyakinan bahwa prospek perusahaan baik, maka manajer akan mengkomunikasikannya kepada investor, dimana investor diharapkan akan menangkap sinyal tersebut dan menilai perusahaan lebih tinggi.

\section{Analisis Fundamental}

Ang (1997:18.2) menjelaskan bahwa analisis fundamental pada dasarnya adalah melakukan analisis historis atas kekuatan keuangan dari suatu perusahaan, yang mana proses ini disebut juga company analysis . Data yang digunakan dalam analisa adalah data historis, artinya data yang telah terjadi dan mencerminkan keadaan keuangan yang telah lewat, bukan mencerminkan keadaan keuangan yang sebenarnya pada waktu analisa.

Analisis fundamental berkaitan dengan penilaian kinerja perusahaan, tentang efektifitas dan efisiensi perusahaan mencapai sasarannya (Stoner et al dalam Korawijayanti, 2014:50)

\section{Laporan Keuangan}

Laporan akuntansi disiapkan untuk memberikan informasi yang berguna bagi para pemakai laporan (users), terutama sebagai dasar pertimbangan dalam proses pengambilan keputusan kelak. Laporan akuntansi ini dinamakan laporan keuangan. Laporan keuangan (financial statements) merupakan produk akhir dari serangkaian proses pencatatan dan pengikhtisaran data transaksi bisnis ( Hery, 2018:2).

Menurut Munawir (2016:2), laporan keuangan adalah hasil dari proses akuntansi yang dapat digunakan sebagai alat berkomunikasi antara data keuangan atau aktivitas suatu perusahaan dengan pihak-pihak yang berkepentingan dengan data atau aktivitas perusahaan tersebut.

\section{Pertumbuhan Laba}

Laba merupakan salah satu indikator kinerja suatu perusahaan. Untuk menghasilkan laba,perusahaan harus melakukan aktivitas operasional. Aktivitas dalam rangka memperoleh laba ini dapat terlaksana jika perusahaan memiliki sejumlah 
sumber daya. Hubungan antar sumber daya yang membentuk aktivitas tersebut dapat ditunjukkan oleh rasio keuangan. Kondisi likuiditas solvabilitas/leverage, aktivitas profitabilitas dan nilai perusahaan mempengaruhi pertumbuhan laba yangakan dicapai suatu perusahaan. Hal ini dikarenakan kondisi-kondisi tersebut menunjukkan keadaan sumber daya perusahaan yang mampu menghasilkan laba (Amalina \& Sabeni, 2014:2)

Dwi dkk dalam Napitupulu (2019:116) menyatakan bahwa laba ada beberapa jenis yaitu laba bruto, laba sebelum pajak, laba tahun berjalan dan laba per saham. Laba bruto berasal dari pendapatan dikurangi dengan beban pokok penjualan. Laba sebelum pajak adalah total laba sebelum pajak penghasilan. Laba tahun berjalan merupakan hasil neto laba perusahaan selama satu periode perusahaan. Dan laba per saham adalah jumlah laba periode berjalan perl lembar saham yang beredar.

Menurut Harahap dalam Napitupulu (2019:116) pertumbuhan laba adalah rasio yang menunjukkan kemampuan perusahaan meningkatkan laba bersih dibanding tahun sebelumnya. Harahap dalam Sari \& Widarti (2015:4) menjelaskan bahwa laba yang digunakan adalah laba setelah pajak (earning after tax).Pertumbuhan laba dirumuskan sebagai berikut:

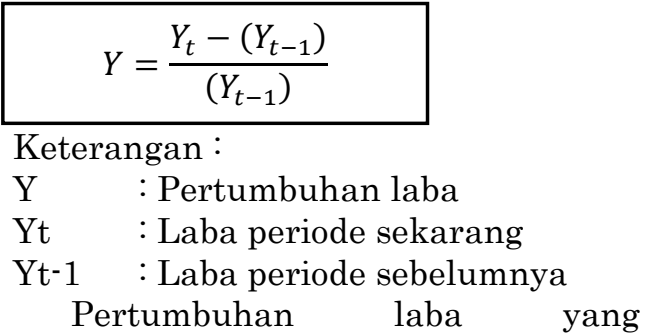
digunakan dalam penelitian ini adalah laba setelah pajak Yt merupakan laba setelah pajak periode tertentu. Yt-1 merupakan laba setelah pajak pada periode sebelumnya.

\section{Analisis Rasio}

Menurut Munawir (2006:64), rasio menggambarkan suatu hubungan atau perimbangan antara suatu jumlah tertentu dengan jumlah yang lainnya, dan dengan menggunakan alat analisis ini akan dapat menjelaskan atau memberi gambaran kepada para penganalisa tentang baik atau buruknya keadaan atau posisi keuangan suatu perusahaan terutama apabila angka rasio tersebut dibandingkan dengan angka rasio pembanding yang digunakan sebagai standar.

Van Horne dan Wachowicz Jr dalam Korawijayanti (2014:50) menjelaskan rasio keuangan dapat menawarkan pandangan yang sangat berharga mengenai kesehatan perusahaan, kondisi keuangan dan profitabilitasnya. Para investor saham umumnya tertarik dengan pendapatan saat ini dan pendapatan yang diharapkan dimasa depan serta stabilitas pendapatan-pendapatan tersebut dalamgaris tren. Jadi, para investor biasanya memfokuskan pada analisis profitabilitas. Mereka juga akan tertarik dengan kondisi keuangan perusahaan yang mempengaruhi kemampuan perusahaan untuk membayar deviden dan menghindari kebrangkutan.

Asian A Umobong (2015:101) mengemukakan bahwa"financial ratios are useful in identifying the key financial variables and the relationshipbetween the variables with intent of giving meaning to the various relationships whileascertaining the strengths and weaknesses of the firm. Its major purpose is to assess thefinancial position and soundness of the firm to which the financial variables relate."

Analisis terhadap laporan keuangan suatu perusahaan pada dasarnya karena ingin mengetahui tingkat keuntungan (profitabilitas) dan tingkat risiko atau tingkat kesehatan suatu perusahaan. Analisis laporan keuangan dapat dilakukan dengan analisis rasio keuangan. Hanafi dan Halim (2009:76) 
mengelompokkan analisis rasio keuangan ke dalam lima macam kategori,yaitu:

a. Rasio Likuiditas

Rasio likuiditas mengukur kemampuan likuiditas jangka pendek perusahaan dengan melihat aktiva lancar perusahaan relatif terhadap hutang lancarnya. Dua rasio likuiditas jangka pendek yang sering digunakan adalah rasio lancar dan rasio quick (acid test ratio).

Rasio lancar mengukur kemampuan perusahaan memenuhi hutang jangka pendeknya dengan menggunakan aktiva lancarnya. Current ratio dapat dihitung dengan formula sebagai berikut:

$$
\text { Current Ratio }=\frac{\text { Aktiva Lancar }}{\text { Hutang Lancar }}
$$

Rasio yang rendah menunjukkan risiko likuiditas yang tinggi, sedangkan rasio lancar yang tinggi menunjukkan adanya kelebihan aktiva lancar, yang akan mempunyai pengaruh yang tidak baik terhadap profitabilitas perusahaan.

b. Rasio Profitabilitas

Rasio profitabilitas mengukur kemampuan perusahaan menghasilkan keuntungan (profitabilitas) pada tingkat penjualan, aset dan modal saham yang tertentu. Ada tiga rasio yang sering dibicarakan, yaitu: profit margin, return on total asset (ROA), dan return on equity (ROE). Rasio return on total asset (ROA) mengukur kemampuan perusahaan menghasilkan laba bersih berdasarkan tingkat aset yang tertentu. ROA dapat dihitung dengan formula sebagai berikut:

$$
\text { ROA }=\frac{\text { Laba Bersih }}{\text { Total Aset }}
$$

Rasio yang tinggi menunjukkan efisiensi manajemen aset, yang berarti efisiensi manajemen. c. Rasio Solvabilitas

Rasio ini $\begin{gathered}\text { mengukur } \\ \text { perusahaan }\end{gathered}$
kemampuan
memenuhi kewajiban-kewajiban jangka panjangnya. Perusahaan yang tidak solvabel adalah perusahaan yang total hutangnya lebih besar dibandingkan tingkat asetnya. Rasio ini mengukur likuiditas jangka panjang perusahaan dan dengan demikian memfokuskan pada sisi kanan neraca. Rasio solvabilitas terdiri dari rasio total hutang terhadap total aset, rasio times interest earned, dan rasio fixed charges coverage.

Debt to total asset menghitung seberapa jauh dana disediakan oleh kreditur. Rasio yang tinggi berarti perusahaan menggunakan leverage keuangan (financial laverage) yang tinggi. Penggunaan financial laverage yang tinggi akan meningkatkan rentabilitas modal saham (return on equity atau ROE) dengan cepat, tetapi sebaliknya apabila penjualan menurun, rentabilitas modal saham (ROE) akan menurun cepat pula. Risiko perusahaan dengan financial leverage yang tinggi akan semakin tinggi pula. Rasio ini dapat dihitung sebagai berikut:

Debt to Total Asset $=\frac{\text { Total Hutang }}{\text { Total Aset }}$

d. Rasio Aktivitas

Rasio ini melihat pada beberapa aset kemudian menentukan berapa tingkat aktivitas aktiva-aktiva tersebut pada tingkat kegiatan tertentu. Aktivitas yang rendah pada tingkat penjualan tertentu akan mengakibatkan semakin besarnya dana kelebihan yang tertanam pada aktiva-aktiva tersebut. Dana kelabihan tersebut akan lebih baik apabila ditanamkan pada aktiva lain yang lebih produktif. Empat rasio aktivitas yang akan dibahas adalah rata-rata umur piutang, perputaran persediaan, perputaran 
aktiva tetap, dan perputaran total aktiva.

Rasio perputaran total aktiva (total assets turnover) menghitung efektifitas penggunaan total aktiva. Rasio yang tinggi biasanya menunjukkan manajemen yang baik, sebaliknya rasio yang rendah harus membuat manajemen mengevaluasi strategi, pemasarannya, dan pengeluaran modalnya. Total assets turnover dapat dihitung dengan formula sebagai berikut:

Total Assets Turnover $=\frac{\text { Penjualan }}{\text { Total Aktiva }}$

Rasio ini menghitung efektivitas penggunaan total aktiva. Rasio yang tinggi biasanya menunjukkan manajemen yang baik, sebaliknya rasio yang rendah harus membuat manajemen mengevaluasi strategi, pemasarannya, dan pengeluaran modalnya (investasi).

e. Rasio Pasar

Rasio pasar mengukur harga pasar relatif terhadap nilai buku. Sudut pandang rasio ini lebih banyak berdasar pada sudut pandang investor (atau calon investor), meskipun pihak manajemen juga berkepentingan terhadap rasio-rasio ini. ada beberapa rasio yang bisa dihitung: PER (price earning ratio), dividend yield, dan pembayaran dividen (dividend payout).

PER melihat harga saham relatif terhadap earning-nya. PER bisa dihitung sebagai berikut:

$$
\text { PER }=\frac{\text { Harga Pasar per Lembar }}{\text { Earning per Lembar }}
$$

Perusahaan yang diharapkan akan tumbuh tinggi (mempunyai prospek yang baik) merupakan perusahaan dengan nilai PER yang tinggi. Dari segi investor, PER yang terlalu tinggi barangkali tidak menarik karena harga saham barangkali tidak akan naik lagi, yang kemungkinan memperoleh capital gain akan lebih kecil.

\section{METODE}

Penelitian ini termasuk penelitian asosiatif dimana penelitian ini bertujuan mengetahui hubungan satu variabel dengan variabel lain. Sehingga dalam penelitian ini akan dibahas hubungan variabel current ratio, return on total assets, debt to total assets, total assets turnover, dan price earning ratio dengan pertumbuhan laba. Adapun teknik pengambilan sampel yang digunakan adalah metode purposive sampling yaitu sampel dipilih dengan menggunakan pertimbangan tertentu yang disesuaikan dengan tujuan penelitian atau masalah penelitian yang dikembangkan.

Menurut sifatnya, data terdiri dari data kualitatif dan kuantitatif. Pada penelitian ini, data yang digunakan adalah jenis data kuantitatif. Data kuantitatif adalah jenis data yang berupa angka-angka yang berasal dari perhitungan masing-masing atribut pengukuran variabel (Chandrarin, 2017:122). Sedangkan menurut sumbernya, data terdiri dari data primer dan data sekunder. Dalam penelitian ini, jenis data yang digunakan adalah data sekunder. Menurut Sekaran (2006:60), data sekunder mengacu pada informasi yang dikumpulkan dari sumber yang telah ada. Dalam penelitian ini, data yang digunakan adalah data sekunder yang berasal dari laporan keuangan perusahaan sampel yang diperoleh dari Bursa Efek Indonesia melalui situs resminya, yaitu www.idx.co.id

Terdapat dua variabel yang digunakan dalam penelitian ini yaitu variabel dependen (Y) dan variabel independen (X). Variabel dependen (terikat) adalah variabel yang dipengaruhi atau yang menjadi akibat, karena adanya variabel bebas (Sugiyono, 2017:61). Adapun variabel dependen dalam penelitian ini adalah pertumbuhan laba.

Variabel independen merupakan variabel yang diduga berpengaruh 
terhadap variabel dependen (Chandrarin, 2017:83). Ada beberapa variabel independen yang digunakan untuk mengukur pengaruh variabelvariabel tersebut terhadap pertumbuhan laba perusahaan. Variabel-variabel tersebut antara lain:current ratio, return on total assets, debt to total assets, total assets turnover, dan price earning rati.

Pengujian hipotesis dalam penelitian ini menggunakan regresi linier berganda, yaitu metode analisis yang menggunakan lebih dari satu variabel independen yang mempengaruhi variabel dependen. Selain itu juga dilakukan uji asumsi klasik yang digunakan untuk menguji apakah model regresi benar-benar menunjukkan hubungan yang signifikan dan representatif yang terdiri dari: Uji Autokorelasi, Uji Normalitas, Uji Multikolinearitas, dan Uji Heterokedastisitas; serta dilakukan Pengujian Determinasi dan Pengujian Hipotesis yang terdiri dari uji F dan uji t. Uji F digunakan untuk mengetahui pengaruh variabel independen terhadap variabel dependen secara simultan. Uji tdigunakan untuk mengetahui pengaruh variabel independen terhadap variabel dependen secara parsial.

\section{HASIL DAN PEMBAHASAN}

Hasil uji regresi berganda dalam penelitian ini adalah sebagai berikut:

\section{Tabel 1 Hasil Uji Regresi Linier Berganda}

\begin{tabular}{lrrrr}
\hline \multicolumn{5}{c}{$\begin{array}{c}\text { Unstandardize } \\
\text { d Coefficients }\end{array}$} \\
Model & \multicolumn{5}{c}{ Std. } \\
\hline 1 Constant & 32.617 & 18.013 & 1.811 & .071 \\
Error & t & Sig. \\
CR & -3.957 & 2.662 & -1.486 & .138 \\
ROA & 175.032 & 36.471 & 4.799 & .000 \\
DAR & -13.731 & 27.364 & -.502 & .616 \\
TATO & -25.398 & 6.946 & -3.657 & .000 \\
PER & -.018 & .025 & -.703 & .482 \\
\hline
\end{tabular}

a. Dependent Variable: Pertumbuhan Laba
Sumber : Data sekunder yang diolah

Dari tabel di atas dapat diketahui bahwa tidak semua variabel independen yang diteliti berpengaruh signifikan terhadap variabel dependen. Dengan demikian dapat dibuat persamaan matematis sebagai berikut.

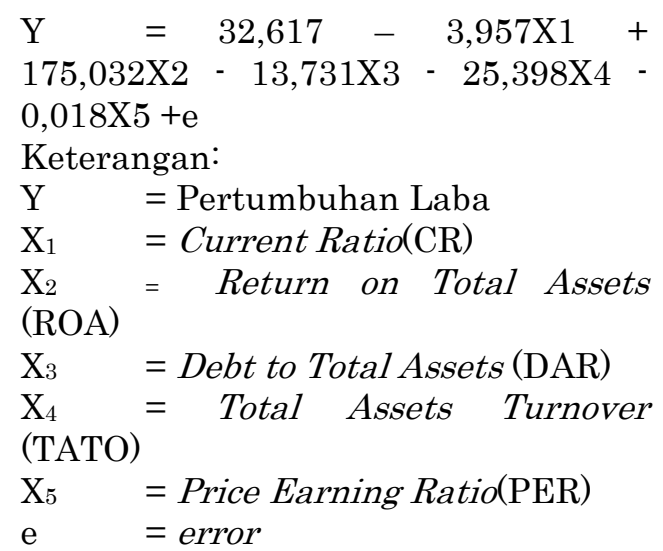

Persamaan regresi di atas, dapat dijelaskan sebagai berikut :

a. Nilai koefisien regresi current ratio sebesar 3,957 bernilai negatif, artinya apabila current ratio meningkat sebesar satu persen, maka pertumbuhan laba akan menurun sebesar 3,957 persen.

b. Nilai koefisien regresi return on total asset sebesar 175,032 bernilai positif, artinya apabila return on total assets meningkat sebesar satu persen, maka pertumbuhan laba akan meningkat sebesar 175,032 persen.

c. Nilai koefisien regresi debt to total asset sebesar 13,731 bernilai negatif, artinya apabila debt to total asset meningkat sebesar satu persen, maka pertumbuhan laba akan menurun sebesar 13,731 persen.

d. Nilai koefisien regresi total asset turnover sebesar 25,398 bernilai negatif, artinya apabila total assets turnover meningkat sebesar satu persen, maka pertumbuhan laba akan menurun sebesar 25,398 persen.

e. Nilai koefisien regresi price earning ratio sebesar 0,018 bernilai negatif, 
artinya apabila price earning ratio meningkat sebesar satu persen, maka pertumbuhan laba akan menurun sebesar 0,018 persen.

Tabel 2 Hasil Uji F

\begin{tabular}{llll} 
Model & F & Sig. \\
\hline 1 & Regressio & 5.580 & $.000^{\mathrm{a}}$ \\
$\mathrm{n}$ & & \\
& Residual & & \\
& & \\
& Total & &
\end{tabular}

Sumber : Data sekunder yang diolah

Hasil uji simultan, diketahui nilai $\mathrm{F}_{\text {tabel }}$ adalah2,2476. Berdasarkan Uji F pada output di atas, dapat dilihat nilai $\mathrm{F}_{\text {hitungsebesar } 5.580>\mathrm{F}_{\text {tabel }} \text { yang hanya }}$ sebesar 2,2476. Tabel uji $\mathrm{F}$ di atas menunjukkan hasil uji statistik dengan signifikansi sebesar 0,000 yang nilainya lebih kecil dari taraf signifikansi 0,05. Dengan ketentuan bahwa nilai signifikansi kurang dari 0,05 serta $F_{\text {hitung }}$ lebih besar dari $F_{\text {tabel }}$ maka dapat diartikan bahwa ada pengaruh yang signifikan dari variabel bebas secara bersama-sama terhadap variabel dependen. Dengan kata lain Current Ratio (CR), Return on Total Assets (ROA), Debt to Total Assets (DAR), Total Assets Turnover (TATO), dan Price Earning Ratio (PER) secara bersama-sama mempengaruhi pertumbuhan laba.

\section{Tabel 3 Hasil Uji t}

\begin{tabular}{llrl} 
Model & $\mathrm{t}$ & \multicolumn{1}{l}{ Sig. } \\
\hline 1 & (Constant & 1.811 & .071 \\
& ) & & \\
CR & -1.486 & .138 \\
ROA & 4.799 & .000 \\
DAR & -.502 & .616 \\
TATO & -3.657 & .000 \\
PER & -.703 & .482 \\
\hline
\end{tabular}

Sumber : Data sekunderyang diolah

Tabel diatas menunjukan nilai $\mathrm{t}$ hitung untuk masing-masing variabel:

\section{Hipotesis 1}

Berdasarkan hasil uji statistik thitung menunjukan signifikansi current ratio yaitu sebesar -1,486 dengan probabilitas $\quad 0,138$. Apabila dibandingkan dengan tabel dan nilai probabilitas $t$ dengan taraf signifikansi 0,05 menunjukkan hasil yang tidak signifikan, karena nilai thitung $-1,4861$ lebih besar dari tabel 1,9688 dan probabilitas t 0,138 lebih besar dari taraf signifikansi 0,05 . Hal ini menunjukkan, bahwa current ratio tidak berpengaruh signifikan dalam memprediksi pertumbuhan laba mendatang.

\section{Hipotesis 2}

Berdasarkan hasil uji statistik thitung menunjukan signifikansi return on total asset yaitu sebesar 4,799 dengan probabilitas 0,000 . Apabila dibandingkan dengan tabel dan nilai probabilitas $t$ dengan taraf signifikansi 0,05 menunjukkan hasil yang signifikan, karena nilai thitung 4,799 lebih besar dari tabel 1,9688 dan probabilitas t 0,000 lebih kecil dari taraf signifikansi 0,05. Hal ini menunjukkan bahwa return on total asset berpengaruh signifikan dalam memprediksi pertumbuhan laba mendatang.

\section{Hipotesis 3}

Berdasarkan hasil uji statistik thitung menunjukan signifikansi debt to total asset yaitu sebesar -0,502 dengan probabilitas $\quad 0,616$. Apabila dibandingkan dengan $t_{\text {tabel }}$ dan nilai probabilitas $t$ dengan taraf signifikansi 0,05 menunjukkan hasil yang tidak signifikan, karena nilai thitung $-0,502$ lebih besar dari tabel 1,9688 dan probabilitas t 0,616 lebih besar dari taraf signifikansi 0,05 . Hal ini menunjukkan bahwa debt to total asset tidakberpengaruh signifikan dalam memprediksi pertumbuhan laba mendatang.

\section{Hipotesis 4}

Berdasarkan hasil uji statistik thitung menunjukan signifikansi total assets turnover yaitu sebesar -3,657 
dengan probabilitas 0,000 . Apabila dibandingkan dengan tabel dan nilai probabilitas $t$ dengan taraf signifikansi 0,05 menunjukkan hasil yang signifikan, karena nilai thitung3,657 lebih kecil dari tabel $^{-1,9688}$ dan probabilitas t 0,000 lebih kecil dari taraf signifikansi 0,05 . Hal ini menunjukkan bahwa total assets turnover berpengaruh signifikan dalam memprediksi pertumbuhan laba mendatang.

\section{Hipotesis 5}

Berdasarkan hasil uji statistik thitung menunjukan signifikansi price earning ratio yaitu sebesar $-0,703$ dengan probabilitas 0,482. Apabila dibandingkan dengan tabel dan nilai probabilitas $t$ dengan taraf signifikansi 0,05 menunjukkan hasil yang tidak signifikan, karena nilai thitung $-0,703$ lebih besar dari tabel 1,9688 dan probabilitas t 0,482 lebih besar dari taraf signifikansi 0,05 . Hal ini menunjukkan bahwa price earning ratio tidakberpengaruh signifikan dalam memprediksi pertumbuhan laba mendatang.

Tabel 4 Hasil Uji Koefisiensi Determinasi

\begin{tabular}{lrrr}
\hline Model & R & R Square & $\begin{array}{r}\text { Adjusted } \\
\text { R Square }\end{array}$ \\
\hline 1 & $.307^{\mathrm{a}}$ & .094 & .077
\end{tabular}

Sumber : Data sekunder yang diolah

Tabel diatas memperlihatkan bahwa nilai adjusted $\mathrm{R}^{2}$ yang diperoleh adalah 0,077 , atau sama dengan $\quad 7,7 \%$. Keadaan ini menunjukkan bahwa variabel independen yaitu Current Ratio (CR), Return on Total Assets (ROA), Debt to Total Assets (DAR), Total Assets Turnover (TATO), dan Price Earning Ratio (PER) memberi kontribusi pengaruh sebesar 7,7 persen terhadap tingkat variabel dependen yaitu pertumbuhan laba. Sedangkan sisanya $92,3 \%$ dipengaruhi oleh variabel lain yang tidak disebutkan dalam penelitian ini misalnya adalah ukuran perusahaan (Sayekti dan Sumarno Dwi Saputra, 2015). Selain itu, menurut Devi Riana dan Lucia Ari Diyani (2016), pertumbuhan laba juga dapat dipengaruhi oleh faktor ekonomi makro seperti tingkat inflasi, pertumbuhan ekonomi, dan kebijakan kenaikan dan penurunan harga yang ditetapkan pemerintah.

\section{HASIL DAN PEMBAHASAN}

Berdasarkan perhitungan statistik, secara parsial current ratio tidak berpengaruh signifikan terhadap pertumbuhan laba. Hal ini dibuktikan dengan nilai signifikansi current ratio 0,136 yang lebih besar dari taraf signifikansi $(0,05)$. Dengan hasil tersebut, maka hipotesis pertama yang menyatakan ada pengaruh antara current ratio dengan pertumbuhan laba ditolak. Hal ini menunjukkan bahwa kenaikan current ratio tidak mempengaruhi jumlah pertumbuhan laba perusahaan manufaktur. Current ratio mengukur kemampuan perusahaan memenuhi hutang jangka pendeknya dengan menggunakan aktiva lancarnya. Pada umumnya rasio ini merupakan salah satu tolok ukur pembiayaan perusahaan. Namun, pada penelitian ini dihasilkan data bahwa current ratio tidak berpengaruh terhadap pertumbuhan laba. Hal ini dapat diasumsikan bahwa current ratio yang digunakan sebagai pembiayaan kinerja perusahaan tidak selalu menjamin pertumbuhan laba. Hal ini dapat menunjukkan bahwa perusahaan yang memiliki aktiva lancar yang tinggi namun tidak memberikan jaminan ketersediaan modal kerja untuk mendukung kegiatan operasional perusahaan current ratio yang tinggi menunjukkan kelebihan aktiva lancar. Kelebihan aktiva lancar tidak menjamin bahwa perusahaan dapat memperoleh laba yang tinggi pula. Hal ini sesuai dengan penelitian yang dilakukan oleh Devi Riana dan Lucia Ari Diyani (2016) yang menyatakan bahwa Rasio likuiditas (CR, QR, WCTA) tidak berpengaruh dalam 
memprediksi perubahan laba satu sampai dua tahun mendatang.

Pengaruh Return on Total Assets
Terhadap Pertumbuhan Laba
Hasil analisis menunjukkan
bahwa return on total assets
berpengaruh signifikan positif
terhadap pertumbuhan laba.
Dibuktikan dengan nilai signifikansi return on total assets 0,000 lebih kecil dari taraf signifikansi 0,05 . Dengan hasil tersebut, maka hipotesis kedua yang menyatakan ada pengaruh antara return on total assets terhadap pertumbuhan laba diterima. Return on total asset mengukur kemampuan perusahaan menghasilkan laba bersih berdasarkan tingkat aset tertentu (Hanafi \& Halim, 2009:84). Munawir (2016:88) menyebutkan rasio ini menghubungkan keuntungan yang diperoleh dari operasi perusahaan. Wibowo \& Pujiati (2011:160) menjelaskan bahwa ROA berfungsi untuk mengukur efektivitas perusahaan dalam menghasilkan laba dengan memanfaatkan aktiva yang dimiliki. Semakin besar ROA yang dimiliki oleh sebuah perusahaan maka semakin efisien penggunaan aktiva sehingga akan memperbesar laba. Return on total asset menunjukkan kemampuan perusahaan untuk menghasilkan laba berdasarkan pemanfaatan aset-aset yang dimiliki sehingga memiliki nilai prediktif dalam menghasilkan laba. Semakin tingginya ROA dapat diartikan bahwa semakin besar kemampuan perusahaan mengelola aktiva yang dimiliki secara efektif dan efisien, sehingga dapat mendorong pertumbuhan laba. Nilai ROA yang tinggi menunjukkan bahwa perusahaan telah efisien dalam memanfaatkan aktivanya untuk memperoleh laba. Hal ini sesuai dengan penelitian yang dilakukan oleh Meilyanti (2017) yang menyimpulkan bahwa terdapat pengaruh yang signifikan antara variabel return on total assets terhadap pertumbuhan laba.

\section{Pengaruh Debt to Asset Terhadap Pertumbuhan Laba \\ Debt to total asset merupakan} rasio utang yang digunakan untuk mengukur perbandingan antara total utang dengan total aktiva. Dengan kata lain, seberapa besar aktiva perusahaan dibiayai oleh utang atau seberapa besar utang perusahaan berpengaruh terhadap pengelolaan aktiva (Kasmir, 2010:156). Rasio ini menggambarkan besarnya kepercayaan kreditur kepada perusahaan melalui dana yang dipinjamkan dapat memperlancar aktivitas perusahaan. Kelancaran aktivitas perusahaan sangat berpengaruh terhadap kegiatan produksi dan penjualan untuk menghasilkan laba. Semakin besar debt to asset ratio, maka semakin besar pula utang yang digunakan perusahaan untuk memenuhi kegiatan operasional perusahaan untuk meningkatkan laba perusahaan Dalam penelitian ini, hasil analisis menunjukkan bahwa debt to total asset tidak berpengaruh signifikan terhadap pertumbuhan laba. Dibuktikan dengan nilai signifikansi 0,616 lebih besar dari 0,05. Dengan hasil tersebut, maka hipotesis ketiga yang menyatakan ada pengaruh antara debt to asset dengan pertumbuhan laba ditolak. Hasil ini sesuai dengan penelitian yang telah dilakukan oleh Amalia Yuigananda, Riana R Dewi, dan Endang Masitoh (2019) yang menyimpulkan bahwa debt to total assets tidak berpengaruh terhadap perubahan laba. Hal ini menggambarkan bahwa tidak adanya efisiensi kinerja dalam mengoptimalkan aktiva untuk menjamin utang perusahaan. Dengan utang yang tinggi mengindikasikan bahwa perusahaan mealokasikan dana yang seharusnya dapat digunakan untuk kegiatan operasional perusahaan, digunakan untuk membayar utang perusahaan. Sehingga, perusahaan tidak dapat meningkatkan laba perusahaan. 
$\begin{array}{llr}\text { Pengaruh Total Assets Turnover } & \text { Tu } \\ \text { terhadap Pertumbuhan Laba } & \\ \text { Hasil analisis menunjukkan } \\ \text { bahwa Total assets } & \text { turnover } \\ \text { berpengaruh signifikan } & \text { negatif } \\ \text { terhadap pertumbuhan laba. }\end{array}$ Dibuktikan dengan nilai signifikansi 0,000 lebih kecil dari 0,05. Dengan hasil tersebut, maka hipotesis keempat yang menyatakan ada pengaruh antara Total assets turnover terhadap pertumbuhan laba diterima. Hasil ini sesuai dengan penelitian Riana dan Diyani (2016) yang menyebutkan bahwa total assets turnover berpengaruh dalam memprediksi perubahan laba satu sampai dua tahun mendatang.

Total assets turnover merupakan rasio yang digunakan untuk mengukur perputaran semua aktiva yang dimiliki perusahaan dan mengukur berapa jumlah penjualan yang diperoleh dari tiap rupiah aktiva (Kasmir, 2010:185). Dengan mengetahui tingkat penjualan perusahaan, laba perusahaan dapat diperkirakan. Total assets turnover yang tinggi memiliki pengaruh terhadap pertumbuhan laba perusahaan. Hal ini berarti perusahaan sudah efektif dalam mengelola aktivanya dan penjualannya.

\section{Pengaruh Price Earning Ratio Terhadap Pertumbuhan Laba \\ Hasil analisis menunjukkan} bahwa price earning ratio tidak berpengaruh signifikan terhadap pertumbuhan laba. Dibuktikan dengan nilai signifikansi 0,482 lebih besar dari 0,05. Dengan hasil tersebut, maka hipotesis kelima yang menyatakan ada pengaruh antara price earning ratio dengan pertumbuhan laba ditolak. Hasil ini sesuai dengan penelitian yang dilakukan oleh Nur Amalina dan Arifin Sabeni (2014) yang menyimpulkan bahwa tidak terdapat pengaruh positif antara price earning ratio terhadap perubahan laba.

Price earning ratio menggambarkan earning yang terkandung disetiap harga per lembar sahamnya. Rasio ini menggambarkan prospek perusahaan. Dengan mengetahui prospek perusahaan, investor mendapatkan pertimbangan dalam keputusan investasi yang selanjutnya investasi modal tersebut digunakan untuk aktivitas perusahaan dalam proses produksi dan penjualan untuk menghasilkan laba. Namun, PER tidak selalu dapat mendorong laba perusahaan.

Pengaruh Current Ratio (CR), Return on Total Assets (ROA), Debt to Total Assets (DAR), Total Assets Turnover (TATO), dan Price Earning Ratio (PER) Terhadap Pertumbuhan Laba

Hasil penelitian menunjukkan bahwa Current Ratio (CR), Return on Total Assets (ROA), Debt to Total Assets (DAR), Total Assets Turnover (TATO), dan Price Earning Ratio (PER) secara simultan berpengaruh signifikan terhadap pertumbuhan laba. Dengan demikian hipotesis keenam yang menyatakan bahwa Current Ratio (CR), Return on Total Assets (ROA), Debt to Total Assets (DAR), Total Assets Turnover (TATO), dan Price Earning Ratio (PER) berpengaruh terhadap pertumbuhan laba dapat diterima.

Current ratio, return on total asset, debt to total asset, total assets turnover, dan price earning ratio mempunyai peran dalam perhitungan analisis rasio yang merupakan bagian penting dari informasi keuangan. Dengan analisis rasio menggunakan kelima variabel tersebut, memungkinkan untuk dapat menentukan derajat keuntungan suatu perusahaan. Sehingga, dengan analisis rasio-rasio keuangan tersebut dapat memprediksi pertumbuhan laba untuk masa yang akan datang.

Hasil penelitian dengan menggunakan uji parsial (t) menghasilkan nilai signifikansi untuk masing-masing variabel independen, yaitu: current ratio sebesar 0,138 ; return on total assets sebesar 0,000 ; debt to total asset sebesar 0,616 ; total asset turnover sebesar 0,000; dan 
price earning ratio yaitu sebesar 0,482. Dari hasil ini, hanya variabel return on total assets dan total assets turnover yang menghasilkan nilai signifikansi di bawah taraf signifikansi 0,05 . Artinya, hanya variabel return on total assets dan total assets turnover yang berpengaruh signifikan terhadap variabel dependen pertumbuhan laba. Hasil ini sesuai dengan penelitian yang telah dilakukan Meilyanti (2017) yang menyimpulkan bahwa terdapat pengaruh yang signifikan antara variabel return on total assets terhadap pertumbuhan laba. Serta penelitian Riana dan Diyani (2016) yang menyebutkan bahwa total assets turnover berpengaruh dalam memprediksi perubahan laba satu sampai dua tahun mendatang.

Hasil penelitian dengan menggunakan uji simultan (f) menghasilkan uji statistik dengan signifikansi sebesar 0,000. Dengan ketentuan bahwa nilai signifikansi kurang dari 0,05 artinya bahwa ada pengaruh yang signifikan dari variabel bebas secara bersama-sama terhadap variabel dependen. Dengan kata lain Current Ratio (CR), Return on Total Assets (ROA), Debt to Total Assets (DAR), Total Assets Turnover (TATO), dan Price Earning Ratio (PER) secara bersama-sama mempengaruhi pertumbuhan laba.

Hasil pengujian koefisien determinasi (R2) memperlihatkan bahwa nilai adjusted R2 yang diperoleh adalah 0,077, atau sama dengan $\quad 7,7 \%$. Keadaan ini menunjukkan bahwa variabel independen yaitu Current Ratio (CR), Return on Total Assets (ROA), Debt to Total Assets (DAR), Total Assets Turnover (TATO), dan Price Earning Ratio (PER) memberi kontribusi pengaruh sebesar $7,7 \%$ terhadap tingkat variabel dependen yaitu pertumbuhan laba. Sedangkan sisanya $92,3 \%$ dipengaruhi oleh variabel lain yang tidak disebutkan dalam penelitian ini misalnya adalah ukuran perusahaan (Sayekti dan Sumarno Dwi Saputra, 2015). Selain itu, menurut Devi Riana dan Lucia Ari Diyani (2016), pertumbuhan laba juga dapat dipengaruhi oleh faktor ekonomi makro seperti tingkat inflasi, pertumbuhan ekonomi, dan kebijakan kenaikan dan penurunan harga yang ditetapkan pemerintah.

\section{SIMPULAN}

Berdasarkan hasil pembahasan analisis data melalui pembuktian terhadap hipotesis dari permasalahan yang diangkat mengenai faktor yang mempengaruhi pertumbuhan laba pada perusahaan manufaktur yang terdaftar di Bursa Efek Indonesia pada tahun 2013 hingga 2017, maka dapat diambil kesimpulan dari penelitian berdasar hasil pengujian secara parsial menunjukkan bahwa:

1. Berdasarkan hasil uji $t$ menunjukan signifikasi current ratio yaitu sebesar 0,138 lebih besar dari 0,05 sehingga hal ini menunjukkan bahwa secara parsial current ratio tidak berpengaruh terhadap pertumbuhan laba.

2. Berdasarkan hasil uji t menunjukan signifikasi return on total assets yaitu sebesar 0,000 lebih kecil dari 0,05 sehingga dapat disimpulkan bahwa secara parsial return on total assets berpengaruh terhadap pertumbuhan laba.

3. Berdasarkan hasil uji $t$ menunjukan signifikasi debt to total asset yaitu sebesar 0,616 lebih besar dari 0,05 ini menjelaskan bahwa debt to total asset tidak berpengaruh terhadap pertumbuhan laba.

4. Berdasarkan hasil uji $t$ menunjukan signifikasi total asset turnover yaitu sebesar 0,000 lebih kecil dari 0,05 sehingga dapat dinyatakan bahwa total asset turnover berpengaruh terhadap pertumbuhan laba.

5. Berdasarkan hasil uji $t$ menunjukan signifikasi price earning ratio yaitu sebesar 0,482 lebih besar dari 0,05 sehingga dapat dinyatakan bahwa price earning ratio tidak 
berpengaruh terhadap pertumbuhan laba.

6. Berdasarkan uji F, dengan hasil signifikansi sebesar 0,000 kurang dari taraf signifikansi 0,05 dapat diartikan bahwa Current Ratio (CR), Return on Total Assets (ROA), Debt to Total Assets (DAR), Total Assets Turnover (TATO), dan Price Earning Ratio (PER) secara simultan dapat mempengaruhi pertumbuhan laba.

\section{DAFTAR PUSTAKA}

Amalina, Nur dan Arifin Sabeni. 2014. Analisis Rasio Keuangan dalam Memprediksi Perubahan Laba : (Studi Empiris pada Perusahaan Manufaktur yang terdaftar pada Bursa Efek Indonesia Periode Tahun 2008-2011). Diponegoro Journal of Accounting, 3 No. 1, 1-15.

A-ng, Robbert. 1997. Buku Pintar Pasar Modal Indonesia. Mediasoft Indonesia

Asian A Umobong, F. 2015. Assessing the impact of Liquidity and Profitability Ratios on Growth of Profits in Pharmaceutical Firms in Nigeria. European Journal of Accounting and Finance Research, 13 no. 10, 97-114.

Brigham, Eugene F, dan Joel F. Houston. 2014. Dasar-dasar Manajemen Keuangan (11 ed.). (A. A. Yulianto, Penerj.) Jakarta: Salemba Empat.

Chandrarin, Grahita. 2017. Metode Riset Akuntansi Pendekatan Kuantitaif. Jakarta: Salemba Empat.

Hanafi, Mamduh M dan Abdul Halim. 2009. Analisis Laporan Keuangan (4 ed.). Yogyakarta: UPP STIM YKPN.
Hery. 2016. Analisis Laporan Keuangan. Jakarta: PT Grasindo.

Kasmir. 2010. Analisis Laporan Keuangan (1 ed.). Jakarta: PT Rajagrafindo Persada.

Korawijayanti, Lardin. 2014. Analisis Perbedaan Pengaruh Faktorfaktor Fundamental dan Kurs terhadap Return Saham antara Perusahaan PMA dengan PMDN . JABPI, 49-60.

Meilyanti. 2017. Analisis Pengaruh Rasio Keuangan terhadap Pada Pertumbuhan Laba Sub Sektor Makanan dan Minuman di Bursa Efek Indonesia Periode Tahun 2012-2016. eJournal Administrasi Bisnis, 5 no. 2, 1000-1013. Diambil kembali dari ejournal.adbis.fisipunmul.ac.id

Munawir. 2016. Analisa Laporan Keuangan (4 ed.). Yogyakarta: Liberty.

Napitupulu, Rina Dameria. 2019. Determinasi Rasio Likuiditas dan Rasio Profitabilitas terhadap Pertumbuhan Laba pada Perusahaan yang terdaftar di Bursa Efek Indonesia. Journal Information System, Applied Management, Accounting, and Research, 3 No. 2, 115-120.

Riana, Devi dan Lucia Ari Diyani. 2016. Pengaruh Rasio Keuangan dalam Memprediksi Perubahan Laba pada Industri Farmasi. Jurnal Online Insan Akuntan, 1 no. 1, 16-42.

Sari, Ratna Candra dan Zuhrohtun. 2006. "Keinformatifan Laba di Pasar Obligasi danSaham : Uji Liquidation Option Hypothesis”. Simposium Nasional Akuntansi gPadang. 
Sari, Linda Purnama dan Endang Tri Widyarti. 2015. Analisis Pengaruh Rasio Keuangan terhadap Pertumbuhan Laba. Diponegoro Journal of Management, 4 No. 4, 1-11.

Sayekti, \& Sumarno Dwi Saputra. 2015. Analisis Pengaruh Rasio Keuangan terhadap Pertumbuhan Laba pada Industri Rokok yang terdaftar di Bursa Efek Indonesia. Jurnal Ekonomi dan Kewirausahaan, 15, 115-121.

Sekaran, Uma. 2006. Research Methods for Business (4 ed.). Jakarta: Salemba Empat.

Sugiyono. 2017. Metode Penelitian Pendidikan. Bandung: Alfabeta.

Yuigananda, Amalia, Riana R. Dewi, dan Endang Maisitoh. 2019. Pengaruh Rasio Keuangan terhadap Perubahan Laba. Proseding Seminar Akuntansi. 2 No. 1.

www.idx.co.id 